Maurice A. Deane School of Law at Hofstra University Scholarly Commons at Hofstra Law

Hofstra Law Faculty Scholarship

2009

\title{
Reproductive Rights and the Reproduction of Gender
}

Barbara Stark

Maurice A. Deane School of Law at Hofstra University

Follow this and additional works at: https://scholarlycommons.law.hofstra.edu/faculty_scholarship

\section{Recommended Citation}

Barbara Stark, Reproductive Rights and the Reproduction of Gender Gender equality : dimensions of women's equal citizenship 345 (2009)

Available at: https://scholarlycommons.law.hofstra.edu/faculty_scholarship/660

This Article is brought to you for free and open access by Scholarly Commons at Hofstra Law. It has been accepted for inclusion in Hofstra Law Faculty Scholarship by an authorized administrator of Scholarly Commons at Hofstra Law. For more information, please contact lawcls@hofstra.edu. 


\title{
Reproductive Rights and the Reproduction of Gender
}

\author{
Barbara Stark*
}

Women's citizenship rights, that is, their rights to participate in social, economic, cultural, and political life on equal terms with men, are explicitly guaranteed in the Convention on the Elimination of All Forms of Discrimination Against Women (CEDAW, or the "Women's Convention"). These rights include the civil and political rights familiar to Americans from our own Constitution such as freedom of expression and freedom of association. These rights also include less familiar economic and social rights such as the right to work and the right to health. Under CEDAW, these rights are to be ensured in fact as well as in law. This means that CEDAW unequivocally bars what I refer to here as the reproduction of gender, that is, the perpetuation of gendered stereotypes. These include both the stereotype of "citizens" as male, ${ }^{2}$ never pregnant, never breast-feeding, and the stereotype of women as exclusive caregivers, always subject to the endless demands of caregiving, even if not actually pregnant or breast-feeding. Rather, under CEDAW, men are expected to assume caregiving responsibilities, and the state is expected to encourage them to do so. ${ }^{3}$

Reproductive rights, including the right to decide when and whether to bear children, are a key component of the citizenship rights of women. Historically, however, reproduction has been viewed as a key component of women's duties as citizens. As Aristotle pointed out, women reproduce citizens, not only in the sense of rearing and raising them, but quite literally by producing them. ${ }^{4}$ This notion has a

* Sincere thanks to Patricia Kasting and Debbie Swiney for expert research assistance and preparation of the manuscript.

1 Convention on the Elimination of All Forms of Discrimination Against Women, G.A. Res. 34/180 (Dec. 18, 1979).

2 As Brenda Cossman explains earlier in this volume, "citizenship has always been sexed." See Chapter 13 .

3 Convention, at Article 5 (Dec. 18, 1979). Article 5 provides in pertinent part that "States Parties shall take all appropriate measures... to ensure... the recognition of the common responsibility of men and women in the upbringing ... of their children."

4 See D. Brendan Nagle, The Household as the Foundation of Aristotle's Polis (Cambridge: Cambridge University Press, 2006). See also Joan Judge, "Citizens or Mothers of Citizens? Gender and the Meaning of Modern Chinese Citizenship," in Merle Goldman and Elizabeth J. Perry, eds., Changing Meanings of Citizenship in Modern China (Cambridge, MA: Harvard University Press, 2002), at 23. 
contemporary iteration in state natalist policies. States with burgeoning populations, such as China and South Africa, have adopted anti-natalist policies. States with plunging fertility rates, such as Germany and Greece, have adopted pro-natalist policies. Some state natalist policies infringe on women's reproductive rights. Some promote other aspects of women's citizenship rights. Some do both, violating reproductive rights even as they promote other rights.

This chapter examines the tensions between state natalist policies and women's citizenship rights, including their reproductive rights. My thesis is that while state natalist policies need not violate women's other citizenship rights, they often do so in fact, especially when they draw on unacknowledged notions of women's citizenship duties. Careful analysis is necessary, accordingly, to assess whether a particular policy measure is likely to violate reproductive rights or to reproduce gender, thus violating other citizenship rights, in a particular context.

The following section sets out women's citizenship rights in general, and their reproductive rights in particular, under international law. The third section examines anti-natalist policies, particularly those that also seek to promote women's citizenship rights. The fourth section examines pro-natalist policies, focusing on those that attempt to influence women's choices by a range of incentives. I conclude that strong-arm policies that violate rights may have impressive results in the short run, but such policies are apt to backfire over time. Approaches that promote women's reproductive rights as well as their other citizenship rights are more effective in the long run. State natalist policies, whether pro-natalist or anti-natalist, may well be most effective when they incorporate rights; they may well be disastrous when they do not. Rather, fostering women's fuller participation in public life, promoting equality, and making it possible for women (and men) to accommodate reproduction and paid work are more likely to contribute to the long-term success of state projects.

\section{Women's Citizenship Rights Under International Law}

\section{In General}

Women's full participation as citizens is an explicit objective of the Women's Convention, which begins by defining the term discrimination against women to mean "any distinction, exclusion or restriction made on the basis of sex, which has the effect or purpose of impairing or nullifying the recognition, enjoyment or exercise by women ... of human rights and fundamental freedoms in the political, economic, social, cultural, civil or any other field." 5

Article 2 of the Women's Convention further requires the state "to take all appropriate measures, including legislation, to modify or abolish existing laws, regulations, customs and practices which constitute discrimination against women." This is an extremely broad formulation, effectively holding the state responsible for all 
discrimination on the basis of gender, whether through state policy, culture, or private prejudice. ${ }^{6}$ No showing of an intent to discriminate is required. Thus the Women's Convention imposes an affirmative obligation on the state to take whatever steps are necessary to ensure women's full participation as citizens. These include special affirmative measures to bring women up to the starting line.

\section{Reproductive Rights}

In general, reproductive rights are not as well established in international human rights law as other citizenship rights because they focus on issues - conception, pregnancy, childbirth - that affect women more directly than they affect men. Because men do not conceive, become pregnant, give birth, or breast-feed their infants, these experiences are not reflected in traditional rights discourse.

Civil and political rights, in contrast, have been championed by men for more than 200 years. When women seek formal equality, that is, when they demand the same rights as men to freedom of speech, for example, they can rely on welldeveloped equality jurisprudence. When women assert reproductive rights, they are in less well-charted territory. These rights address issues historically and almost universally relegated to the private sphere, left to the determination of the married couple. This both reflects and perpetuates women's subordination within marriage. The idea that women should have control over the number and spacing of their children has been controversial, especially in cultures where large families are viewed as desirable. Nevertheless, reproductive rights are increasingly recognized in international human rights law, as set out below. These rights, including education about family planning and access to contraception, are now widely recognized throughout the world. Almost every state allows access to contraception, and several states provide contraceptives as a free public health benefit.

While reproductive rights are widely recognized as a general principle, the implementation of reproductive rights in the context of state natalist policies raises two major questions. First, are reproductive rights to be exercised by a couple, or by each individual within a couple? If the individuals do not agree, how should the dispute be resolved? Second, under what conditions, and through what mechanisms, can the state seek to influence the exercise of these rights? More specifically, do the particular measures adopted to effectuate state natalist policies violate these rights?

\section{The Civil Covenant}

The International Covenant on Civil and Political Rights (or the Civil Covenant) addresses civil and political rights. Article 3 of the Civil Covenant requires states to "ensure the equal right of men and women to the enjoyment of all civil and political rights," but there is no explicit reference to reproductive rights. While Article 17

6 In addition to state violence, women's reproductive rights may also be violated by domestic violence.

See Elizabeth Schneider's analysis in Chapter 18. 
recognizes a right to "privacy," unlike the right to privacy that the U.S. Supreme Court has found in the U.S. Constitution, 7 the international version has not been construed to include the right to reproductive privacy.

Article 23 of the Civil Covenant ensures the "right of men and women of marriageable age to marry and to found a family" and requires the state to "take appropriate steps to ensure equality of rights and responsibilities of spouses as to marriage, during marriage, and at its dissolution." This applies to state family planning policies, as the Human Rights Committee has pointed out:

The right to found a family implies, in principle, the possibility to procreate and live together. When States parties adopt family planning policies, they should be compatible with the provisions of the Covenant and should, in particular, not be discriminatory or compulsory. ${ }^{8}$

\section{The Economic Covenant}

The International Covenant on Economic, Social, and Cultural Rights (or the Economic Covenant) ensures basic economic and social rights, including the right to health and the right to an adequate standard of living. Unlike the Civil Covenant, it has no counterpart in U.S. jurisprudence. Article 2 and Article 3 of the Economic Covenant require states to "ensure the equal right of men and women to the enjoyment of all economic, social, and cultural rights."

Article 10 of the Economic Covenant requires states to ensure "family rights," and Article 12 requires states to ensure the "right to health." Reproductive rights are crucial to any meaningful understanding of either article. Without reproductive rights, parents cannot determine the most fundamental issues of family membership such as the spacing or number of children.

The right to health can also be invoked to argue against state limits on abortion. As the World Health Organization has noted, the absence of safe, dependable contraception and abortion presents grave risks to the health of women, whether through unsafe abortions (20 million annually), severe maternal morbidity (20 million cases annually), or perinatal deaths ( 7.2 million annually) ${ }^{9}$

While it is clear that state-sponsored or state-sanctioned coerced abortions or sterilizations violate the covenants, it is not clear what kinds of incentives and disincentives, short of brute force, amount to coercion. It has been suggested that any incentives or disincentives by the state should be considered impermissible. ${ }^{10}$ This assumes a neutral background, a level playing field. Where there is strong social coercion,

7 See Griswold v. Conn., 381 U.S. 479 (1965); Eisenstadt v. Baird, 405 U.S. $43^{8}$ (1972); Roe v. Wade, 410 U.S. 113 (1973).

8 Human Rights Committee, General Comment 19 (1990), Article 23, at para. 5 (discussing the International Covenant on Civil and Political Rights),

9 Sev S. Fuluss, "The World Health Organization and Women," in Kelly Askin and Dorean Koenig, eds., Women and International Human Rights Law (Ardsley, NY: Transnational, 1999), at 411.

10 See Rebecca Cook et al., Reproductive Health and Human Rights (Oxford: Oxford University Press, 2003), at 113-14 (explaining providers' duty to promote patients' free decision making). 


\section{Reproductive Rights and the Reproduction of Gender}

however, like the pressure on women in rural China to bear sons, it can be argued that some incentives, such as preferential treatment for small families with respect to housing, may be necessary as a counterweight. Where there are legitimate state interests in discouraging growth, similarly, some incentives for limiting family size might be acceptable. Such interests include the protection of other rights such as the right to an adequate standard of living set out in Article 11 of the Economic Covenant.

Articles 4 and 5 of the Economic Covenant, which address the nonderogation of economic, social, and cultural rights, suggest the parameters for such incentives. Article 4 provides that "the State may subject such rights only to such limitations as are determined by law only in so far as this may be compatible with the nature of these rights and solely for the purpose of promoting the general welfare in a democratic society." As Philip Alston notes, this imposes a rigorous standard: "limitations must, in the first place be 'determined by law' in accordance with the appropriate national procedures and must not be arbitrary or unreasonable or retroactive. The limitations must also 'be compatible with the nature' of these rights."

Article 5 extends the prohibition against derogation in three important ways. First, it extends this prohibition to nonstate third parties. Thus, while a violation under the Civil Covenant requires a showing of state practice, the state cannot avoid responsibility by blaming coercive practices on overzealous local officials. Second, it extends the prohibition to activities indirectly aimed at derogation. A monetary inducement for a late-term abortion, at significant risk to the mother's health, would arguably violate this standard. Third, it prohibits derogation from any other rights on the pretext that the covenant requires such derogation. Thus, where other rights are clearly at risk, such as a child's right to be registered, the covenant does not permit derogation. ${ }^{12}$

\section{The Women's Convention}

The Women's Convention sets out the clearest protection for reproductive rights. Article 11.2 prohibits the state from penalizing women for pregnancy. Article 12 explicitly requires the state to "ensure access to healthcare services, including those related to family planning," and, more specifically, to "ensure to women appropriate services in connection with pregnancy, confinement in the postnatal period, granting free services when necessary, as well as adequate nutrition during pregnancy and lactation." Article 14 reiterates the right to family planning services for rural women in particular. Article 16, relating generally to women's rights within marriage, again emphasizes that women have "the same rights [as men] to decide freely and responsibly on the number and spacing of their children."13

1 Philip Alston, "The International Covenant on Social, Economic, and Cultural Rights," in Manual on Human Rights Reporting (Geneva, Switzerland: United Nations, 1991), at 48.

12 See n. 3 (explaining state responsibility for private actors under CEDAW).

13 As Rebecca Cook has observed, Article 16 received an unprecedented number of reservations. Rebecca Cook, "Reservations to the Convention on the Elimination of All Forms of Discrimination Against Women," 30 Va. J. Int'l L. 643 (1990). The United States is not a party to the Women's Convention. 
While the Women's Convention provides a clear statement of reproductive rights, and measures to be taken to ensure them, enforcement in domestic courts is a separate issue. Although some countries, such as the Netherlands, adopt international human rights treaties as domestic law upon ratification, many, including China, do not. Although such states may have ratified the Women's Convention, it is not enforceable as domestic law. This means that women in these states cannot claim their rights under the convention in their national courts. Nor is there any international tribunal before which they may do so. An Optional Protocol to the Women's Convention enables individual women to file complaints before the CEDAW Committee, which is responsible for implementation of the convention. This is not an option for Chinese women because China is not a party to the protocol. Thus Chinese women cannot rely on the formal guarantees of reproductive rights under the Women's Convention.

\section{Anti-natalist Policies}

Burgeoning populations impose intolerable strains on developing states. The problems of inadequate infrastructure - including the lack of roads, hospitals, schools, access to clean water, and electricity - are exacerbated by deeply entrenched cultural preferences for large families. In China, for example, large families have long been the ideal, especially for the vast majority of the population living in rural areas. ${ }^{14}$ As in most agrarian, preindustrial societies, children were valued as laborers. Boys were considered more important to their parents, in part because girls joined their husbands' families upon marriage. Sons were their parents' social security and old age insurance. ${ }^{15}$ The birth of a boy was regarded as a "big happiness"; the birth of a girl was viewed as a "small happiness."16

By 1980, however, China's Communist leadership viewed the rapidly multiplying population as a major national crisis, ${ }^{17}$ jeopardizing all other national policies, including those regarding modernization and economic stability. ${ }^{18}$ Fertility rates of over five live births per woman would make it impossible to improve, or even maintain, the dismal standard of living. The country faced imminent disaster, including widespread famine.

14 Mark Savage, "The Law of Abortion in the Union of Soviet Socialist Republics and the People's Republic of China: Women's Rights in Two Socialist Countries," 40 Stan. L. Rev. 1027, 1069, 1081 (1988).

15 Ibid.

16 See Barbara Jones, "A Small Happiness," Families With Children From China, available at http:// www.fwcc.org/ (accessed Oct. 11, 2008).

17 China's first modern census in 1953 put the population at $583,000,000$. This figure more than doubled in less than fifty years to 1,260,000,000 in 1999. "China's Population Growth 'Slowing," BBC News, available at http://news.bbc.co.uk/ (accessed Oct. 11, 2008).

18 Edwin A. Winckler, "Re-enforcing State Birth Planning," in Transition From Communism in China: Institutional and Comparative Analyses (Boulder, CO: Lynne Rienner, 1999), at 181. 
Although later analyses challenged the statistics compiled by the government, they became the basis for China's infamous one-child policy. The state mobilized its vast bureaucracy to cope with the perceived emergency and crafted a comprehensive population control policy. As Susan Greenhalgh explains,

China presents the world's most conspicuous and consequential case of a topdown, demographic-targeting approach to population control.... Unlike the more familiar family planning program, in which the individual couple is enjoined to plan its family, China has created a state birth planning program, in which social engineers in the state planning apparatus effectively plan the birth(s) of every couple in the nation. ${ }^{19}$

There is some flexibility. Couples in rural areas are permitted to have a second child if their first child is a girl, for example. But China's one-child policy was clearly compulsory and thus a violation of the Civil Covenant. ${ }^{20}$ In addition, the methods adopted to enforce this policy were often harsh, including forced abortions and sterilizations, public humiliation, onerous fines, and the refusal to register unauthorized children, rendering them ineligible for state health care or public education. China was widely condemned for these measures, which it, in fact, denied. Rather, according to China, such measures were the unauthorized acts of "over-zealous local officials." At the same time, China defended the one-child policy as crucial for the assurance of other human rights, especially the right to an adequate standard of living. As the State Council has explained,

Some people who censure China's family planning policy as “violating human rights" and being "inhuman" do not understand or consider China's real situation. China has only two alternatives in handling its population problem: to implement family planning policy or to allow blind growth in births. The former choice enables children to be born and grow up healthily and live a better life, while the latter one leads to unrestrained expansion of population so that the majority of the people will be short on food and clothing, while some will even tend to die young. Which of the two pays more attention to human rights and is more humane? The answer is obvious. ${ }^{21}$

In times of "public emergency," states may derogate from certain rights, including reproductive rights, under the Civil Covenant. As explained previously, China certainly viewed the population crisis in the early 1980 as a public emergency. While forced abortions or sterilizations should be prohibited even under this standard, fines for unauthorized children might be acceptable, if they are not onerous. Even if the

19 Susan Greenhalgh, "Fresh Winds in Beijing: Chinese Feminists Speak Out on the One-Child Policy and Women's Lives," 26 Signs 847, 852 (2001).

$2 \circ$ See sup. n. 8 and accompanying text.

${ }^{21}$ Information Office of the State Council of the People's Republic of China, Human Rights in China, ch. VIII, available at http://www.china.org.cn/ (accessed Sept. 3, 2008) (hereinafter referred to as "State Council Paper"). 
population crisis is no longer considered a public emergency, international human rights laws permit states to limit some rights, if necessary, to ensure "the public welfare." Even if incentives are viewed as limits on rights, accordingly, they would arguably be permissible under this standard. Such permissible limits might include incentives for families with only one child, such as preferred housing or bonuses like those currently offered in some regions.

As codified in China's Law on Population and Family Planning, ${ }^{22}$ the one-child policy remains in effect. It is to be implemented through "publicity and education, advances in science and technology, comprehensive services and the establishment and improvement of the incentive and social security systems." ${ }^{23}$ Indeed, officials violating human rights are now subject to civil and criminal penalties. It is unclear whether this new emphasis on rights is a response to international criticism or to the growing evidence of the ways in which the one-child policy has failed. ${ }^{24}$

In addition to halting population growth, the one-child policy was explicitly intended to promote women's citizenship rights, or women's equality. ${ }^{25}$ China's gains in this regard have been impressive, as summarized in a recent white paper:

Women's status has been raised distinctly.... Currently women amount to over one-third of all government functionaries, managerial personnel in state-owned enterprises and institutions and professionals of all trades. In 1999, employed women amounted to $46.5 \%$ of the entire workforce in China, compared to the world level of $34.5 \%$, and women's income accounted for $80.4 \%$ of men's. ${ }^{26}$

At the same time, the one-child policy has led to millions of "missing" baby girls, that is, baby girls presumably born but no longer alive. In an influential 1990 article, "More Than 100 Million Women Are Missing," Nobel Prize-winning economist Amartya Sen explains that although more boys are born than girls, girls have better survival rates if they receive the same care. ${ }^{27} \mathrm{He}$ then calculates the number of women "missing" in countries where, given the birth ratios, they would be expected to survive if they received the same medical care, food, and social services as men. In China alone, he concludes, 50 million women are missing. Adding this to the numbers missing in south Asia, west Asia, and north Africa, he concludes that over 100 million women are "missing" - women who could have been expected to survive had they had the same access to resources as men. It is unknown how many of these

22 Population and Family Planning Law of the People's Republic of China (Dec. 29, 2001), available at http://www.unescap.org/ (accessed Sept. 3, 2008).

23 CEDAW, Article 3.

24 See inf. n. 27 and accompanying text (explaining how the policy has resulted in "missing" baby girls) and inf. n. $42-43$ (describing the consequences of the shortage of young women).

25 Greenhalgh,. "Fresh Winds."

26 Information Office of the State Council of the People's Republic of China, "China's Population and Development in the 21st Century," available at http://www.china.org.cn/ (accessed Sept. 3, 2008).

27 Amartya Sen, "More Than 100 Million Women Are Missing," New York Times Review of Books, Dec. 20, 1990, at 61-66. 
girls are aborted, which is viewed as a "cleaner" alternative to female infanticide. Sex-selective abortions are illegal in India and China but widely available.

Sex-selective abortion is not a universal problem. In Canada, for example, there is no strong preference for boys or girls. ${ }^{28}$ Sex-selective abortion is not illegal in Canada. Indeed, a ban on such abortions could be viewed as an unwarranted restriction on reproductive choice. Sex-selective abortion becomes a problem only when there is a strong preference for boys, as in India and China. And it becomes an intractable problem when that preference is grounded in brutal economic realities that in fact are violations of core economic rights. In China, for example, the state concedes that social security is inadequate and often nonexistent. The difficulties of establishing such a system are heightened by the aging population. ${ }^{29}$ Without state support, the only hope for aging parents is the support that can traditionally be expected from a son. As women enjoy greater citizenship rights, including greater access to better jobs, this may change. But many Chinese parents are reluctant to bet their futures on the possibility.

Thus, recognizing that either sex-selective abortion or its denial may violate human rights is only the beginning of the analysis. The next step is to consider the broader citizenship rights implicated, including, crucially, the economic right to social security. As many commentators have observed, the Indian law against sexselective abortion is a failure. $3^{\circ}$ Rather than focusing on enforcement, or increasing penalties, it would be more constructive to focus on the underlying economic realities, especially those that implicate the violation of citizenship rights. ${ }^{31}$

Like the Chinese government, the South African government considers the fertility rate to be too high. Its goal is to reduce the fertility rate to the replacement rate of 2.1 children per woman by 2010 . Unlike the Chinese government, the South African government has attempted to do so in a manner compatible with women's reproductive rights. Rather than imposing criminal or other sanctions on women, the government supports family planning services and provides free contraceptives at all government medical establishments. This approach has been effective, resulting in a steady decline of fertility from 5.6 in 1970 , to 3.6 in 1990, to 2.7 in 2007.32

Iran, which is not a party to CEDAW, is probably the most successful example of an anti-natalist state that respects reproductive rights. Iran has shown that population growth can be reversed without violating human rights. Spurred by the 1979 Islamic Revolution, and the exhortation of the Ayatollah Khomeini to "produce soldiers for

28 Cook et al., Reproductive Health, at 365 .

29 Information Office of the State Council, China's Population and Development, “Targets and Principles," at II (explaining that "sex ratio at birth is expected to gradually become normal [as] China would redouble its efforts to solve the problem of ageing of population") (on file with author).

$3^{\circ}$ Cook et al., Reproductive Health, at 368 .

${ }^{31}$ Indeed, the selective imposition of the norm of gender equality in this context, to deny Indian or Chinese women sex-selective abortion while allowing Canadian or American women to abort a fetus on the basis of sex, arguably smacks of colonialism. See Deborah Weissman's warnings about colonialism in Chapter 20.

32 Unicef, "Statistics," available at http://www.unicef.org/ (accessed Sept. 3, 2008). 
Islam," the population doubled from 27 million in 1968 to 55 million in 1988.33 In December 1989, the government reinstated family planning, encouraging couples to space their children and to limit family size. In 1993, a national family planning law was enacted that encouraged women to have fewer children by restricting maternity leave after three children. On its face, this violates Article 11.2, which requires states to provide "maternity leave with pay or with comparable social benefits." Because Iran is not a party to CEDAW, however, it is not in violation. Even if Iran were a party to CEDAW, it is unlikely that this restriction would be deemed a violation. Affirmative obligations under CEDAW, like affirmative obligations under the Economic Covenant, are necessarily subject to reasonable resource constraints, and a noncoercive disincentive to have more than three children would probably be considered reasonable.

This disincentive, moreover, is part of a comprehensive program that often makes such disincentives superfluous. As part of this program, the state-controlled media have raised public awareness about population issues and family planning. The state pays 80 percent of the family planning costs, and birth control is free. A network of clinics and 15,000 "health houses" provides services to 80 percent of the rural population. Religious leaders, importantly, support family planning and have issued fatwas (edicts) encouraging the use of contraceptives. In addition, Iran has taken steps to directly involve men in family planning. It is the only country in the world that requires men as well as women to take a class on contraception before receiving a marriage license.

Finally, family planning is not an isolated initiative. Under a major literacy campaign, for example, women's literacy has increased from less than 25 percent in 1970 to more than 70 percent in 2000.34 The United Nations currently projects that fertility in Iran will drop to replacement level by 2010.35

Iran is not China, of course, and it is difficult to compare their programs. The cooperation of religious leaders in Iran has been crucial to the success of its program, for example, and there is no comparable authority in China. But forced abortion and sterilization violate human rights; drawing on religious culture to support family planning does not. Iran's program shows that impressive reductions in fertility can be achieved without egregious violations of human rights.

\section{Pro-Natalist Policies}

In southern Europe, fertility rates below the 2.1 necessary to replace the population are a source of growing concern..$^{6}$ The German government, for example, considers

33 Janet Larsen, “Iran's Birth Rate Plummeting at a Record Pace: Success Provides a Model for Other Developing Countries," Earth Policy Institute, available at http://www.earth-policy.org/ (accessed March 3, 2009).

34 Ibid.

35 Ibid.

${ }^{6}$ Pro-natalist policies generally focus on incentives for fertile couples, rather than support for reproductive technologies to enable couples to overcome infertility. See Mary Lyndon Shanley's analysis of infertility and social justice in Chapter $\mathbf{1 5}$. 
the fertility rate of 1.3 children per woman too low. Reflecting both respect for women's reproductive rights under international human rights and German law, as well as the lack of consensus among the German political parties on this issue, the government has not intervened with respect to fertility levels, although it does provide indirect support for contraceptive use.

Pro-natalist policies have been criticized for casting women as breeders and consigning them to the private sphere of the home and the family. From Hitler's "medals for mothers" in the 1940s to the Ayatollah's exhortation to Iranian women to produce "soldiers for Islam" in the 1980s, pro-natalist policies have tended to undermine women's citizenship rights.

Sometimes such policies blatantly violate reproductive rights, like the virtual ban on abortion and contraception in Romania under Nicolae Ceausescu. In 1966, Council of State Decree 700 criminalized abortion and radically restricted access to contraceptives. Birth rates soared, as did maternal mortality, mostly from illegal abortions. According to one source, there were "over 10,000 deaths from illegally performed abortions and approximately 5.2 million cases of permanent sterility resulting from faulty ... procedures." 37 The law was rescinded by the new government in 1989, but there were grim consequences, including a sizable cohort of unwanted, neglected, and abandoned children. In other cases, reproductive rights may still be ensured, and the violation of citizenship rights is more subtle. In Italy, for example, stipends for birth, and special allowances for mothers (especially in the absence of maternity leaves and other workplace accommodations), discourage women's “full participation in economic, social, and cultural life" and perpetuate stereotypes in violation of CEDAW. $3^{8}$

Recent research, moreover, suggests that such measures may also be counterproductive. Rather, European demographers have shown that fertility rates are in fact higher in Europe when women are more equal; that is, women who enjoy greater citizenship rights, including, but not limited to, reproductive rights, are more likely to have children than women who do not enjoy such rights. When caregiving responsibilities are viewed solely as women's responsibilities, and mothers are effectively precluded from participating in the work force, fewer women opt to be mothers, and those who do have fewer children. Thus, in northern Europe, where women participate more fully in public life and enjoy greater equality, fertility rates are higher than in southern Europe, which has what demographers call "lowest-low" fertility rates, that is, below 1.3. At this rate, the population is reduced by half every forty-five years. 39 As demographer Hans-Peter Kohler and his coauthors note, this is a response to stereotypical gender roles within families: "fertility falls to very low levels when gender equity rises in ... the labor market, while it remains low" in

37 See D. Marianne Blair and Merle H. Weiner, Family Law in the World Community (Durham, NC: Carolina Academic Press, 2003), at 970 (citing Paula Abrams, "Population Politics: Reproductive Rights and U.S. Asylum Policy," 14 Geo. Immigr. L. J. 881, 887 [2000]).

$3^{8}$ Russell Shorto, "No Babies?," New York Times Magazine, June 29, 2008, at 36.

39 Hans-Peter Kohler et al., "The Emergence of Lowest-Low Fertility in Europe During the 1990s," 28 Population and Dev. Rev. 641 , at $6_{42}$ (2002). 
families. $4^{\circ}$ The key, according to Kohler and his colleagues, is to ensure that childbearing is compatible with female labor force participation. ${ }^{41}$

\section{Conclusion}

State natalist policies do not necessarily violate women's reproductive rights or their other citizenship rights. But such policies, evocative of earlier views of women as the reproducers of citizens, should be considered warily. Such policies may violate rights overtly, like the criminalization of abortion in Romania or coerced sterilizations in China. They may also violate rights by channeling women into domesticity, foreclosing other opportunities and reproducing gender, directly and indirectly. They may violate rights by failing to take deeply entrenched forms of gender subordination into account, like the cultural preference for sons. They may violate rights by failing to take long-range consequences into account, like the probability of destitution for old couples in China without sons. Natalist policies, finally, may have rights implications for future generations, such as the young men in China unable to marry because there simply are not enough young women, ${ }^{42}$ or the young girls in China who are kidnapped from their homes for the same reason. ${ }^{43}$ The protection of reproductive rights is necessary, but not sufficient, to safeguard against the reproduction of gender in the context of state natalist policies. Rather, as Maxine Eichner suggests with respect to theorizing sexual citizenship, "no single lens... should be deemed to have priority" given the intertwining of gender with "other axes of power." 44 By situating women's reproductive rights in the broader context of women's citizenship rights, this chapter has shown why state natalist policies should promote both.

40 Ibid.

$4^{1}$ As Joanna L. Grossman explains, accommodation for pregnant workers is another way in which th labor market can support women's citizenship rights. See Chapter 10.

$4^{2}$ Therese Hesketh, Li Lu, and Zhu Wei Xing, "The Effect of China's One-Child Family Policy Afte 25 Years," 353 N. Eng. J. Med. 1171, 1173 (2005).

43 Ibid.

44 See Chapter 14 . 